\title{
LER A IMAGEM FOTOGRÁFICA, CONTEMPLAR O TEXTO LITERÁRIO: IM(COM)PLICAÇÕES DE LINGUAGEM
}

\author{
SANDRA KLAFKE ${ }^{1}$ \\ Programa de Pós-Graduação em Comunicação \\ Universidade Federal do Mato Grosso do Sul \\ Av. Costa e Silva, s/n - Cidade Universitária. 79070-900. Campo Grande, MS, Brasil \\ sandra klafkedyahoo.com.br
}

\begin{abstract}
Resumo. Este artigo parte da noção de literatura como espaço que cinde a realidade simbólica socialmente partilhada entre os sujeitos, permitindo ao ser humano uma experiência de libertação, a partir de si mesmo e do sentido que advém do texto, no momento em que metalinguisticamente transforma o discurso em imagem. Tendo por base uma problemática que exige o estudo da linguagem, aborda-se a linguagem literária e a língua do homem como bases para a construção da ideia da literatura como fotografia (BARTHES, 2009a , 2009b), partindo do ponto de vista dos estudos enunciativos (BENVENISTE, 1995, 2006, 2014). Como resultado, este texto indica que a literatura e a fotografia são espaços para subjetivação da experiência humana na linguagem, o que permite entender que o texto literário pode emergir como imagem no momento em que rompe com o mundo do significante e promove a sensação de "poderia ser", próxima da ideia barthesiana de punctum.

Palavras-chave: literatura; fotografia; arte; discurso; linguagem.
\end{abstract}

\begin{abstract}
This article starts from the notion of literature as the space that divides the symbolic reality socially shared among the subjects, allowing to the human an experience of liberation, starting from himself and from the meaning that comes from the text, in the moment that in a metalinguistic mode transforms the speech in image. Based on an issue that requires the study of language, is analyzed the literary language and the language of man as basis for the construction of the idea of literature as photography (BARTHES, 2009a, 2009b), starting from the point of view of the enunciative studies (BENVENISTE, 1995, 2006, 2014). As a result, this text indicates that the literature and the photography are spaces to the subjectivation of the human experience in language, that permit to understand that the literary text can emerge as image in the moment that breaks with the world of the significant and promotes the sensation of "it could be", near of the barthesian idea of punctum.
\end{abstract}

Keywords: literature; photography; art; discourse; language.

\footnotetext{
${ }^{1}$ Doutora em Linguística Aplicada pela UNISINOS. Atua como professora voluntária na Universidade Federal de Mato Grosso do Sul.
} 


\section{Introdução}

A literatura é um dos meios através dos quais se constroem e se validam as representações do mundo social. Ainda que não tenha qualquer compromisso com a exposição verossímil do meio tal qual o conhecemos, ela testemunha o emergir de diferentes sujeitos (efeito de discurso) onde, no dizer do filósofo indo-britânico Homi Bhabha (2001, p. 42), a "visibilidade histórica já se apagou" e o presente do indicativo do testemunho perdeu seu poder de capturar, apresentando-nos, frente suas múltiplas faces, "a imagem de nossa sobrevivência psíquica". (idem, 2001, p. 42). Como espaço de representação, na literatura repercutem os mais diversos discursos e as inúmeras semânticas, que requerem que nos posicionemos frente a elas (lugar de recepção, leitura), aderindo ou recusando-as, intervindo e reagindo diante do universo proposto na e pelas obras literárias.

Como objeto de estudo, o texto literário é posto frente a diferentes instrumentos e processos metodológicos de análise, no âmbito daquilo que as teorias da linguagem são capazes de suportar (sentido de suporte; apoio). Hoje, parte da tentativa de pesquisas motivadas pelo fenômeno da linguagem e interessadas pelo campo literário é justamente extrapolar as barreias construídas pela visão formalista de literatura, promovendo o exercício de tocar a linguagem literária em seu estado de arte, buscando subsídios para construir e compreender, nos processos - tanto de recepção como de criação-, como se constitui a relação entre a língua do homem (leia-se o termo no sentido genérico e não de gênero) e a língua em estado de arte (KLAFKE, 2016a).

Porém, é importante destacar que aquilo que se está a designar por língua em estado de arte não é uma língua diferente (sistêmica) da langue saussuriana (SAUSSURE, 2008) ou da língua-discurso (BENVENISTE, 1995; 2006), mas sim uma dimensão de língua que só pode ser alcançada pelo homem que é abismado pela arte, seja ela visual ou não. Esse conceito será mais bem elaborado ao longo deste texto, no entanto deixa-se claro o ponto de vista de que a língua em estado de arte tem origem no sentir que envolve o homem que é captado pelo objeto artístico, ou seja, é no instante em que a arte abisma (no sentido de cindir ser e sujeito) o homem a ponto de revolver sua inscrição simbólica que a língua em estado de arte se manifesta como "[...] potência que provoca o homem em contingencialidade a passar do antropológico para o linguístico [...]”, momento em que ele precisa reencontrar lugar para si na cadeia discursiva e subjetivar " [...] o discurso ${ }^{2}$ motivado pela arte a partir de si e da potência volitivo-emocional desencadeada pela proximidade com a língua em estado de arte" (KLAFKE, 2016a, p. 136).

Desse ponto de vista, é preciso abandonar a ideia de que os "objetos" literários admitem critérios a priori para estudo, uma vez que a multiplicidade de sentidos de uma obra jamais poderá ser "enformada" e encerrada em concepções que massifiquem e rotulem seus alcances estético e sensível. Isso significa que neste texto a literatura é vista como um interrogante, já que se constitui como o espaço (um dos espaços) que permite ao homem transcender para além do par codificação/decodificação de signos, extrapolando, portanto, as barreiras do signo saussuriano, tal como pode ser lido no Curso de Linguística Geral (2008).

\footnotetext{
${ }^{2}$ Discurso, neste artigo, deve ser entendido como o produto de uma enunciação, sendo, portanto, o espaço em que se pode observar o nascimento do sujeito, das inúmeras semânticas e de diferentes vozes sociais.
} 
Sendo assim, é a literatura como ferida, como aquilo que pulsa e testemunha o emergir de um sujeito (efeito de discurso) o que mobiliza a escrita deste artigo, cujo objetivo é abordar a linguagem literária e a língua do homem como bases para a construção da ideia da literatura como fotografia, partindo do ponto de vista dos estudos enunciativos da linguagem. Para além da posição da literatura enquanto área de conhecimento, os argumentos que organizam esta proposta são orientados pelo sincretismo de um olhar transdisciplinar e pela sincronicidade que uma reflexão voltada para as teorias da linguagem pode oferecer.

Para que esse propósito seja cumprido, o emergir da noção de literatura como espaço que irrompe em imagem será observado, de maneira teórico reflexiva, tendo em vista a percepção do receptor da obra, pois, se a literatura pode ser lida tal como a uma fotografia, é porque, assim como a imagem, “[...] ela representará sempre a criação de um testemunho" (KOSSOY, 2012, p. 52). Todavia, o problema que se apresenta na afirmação de Kossoy é de origem, ou seja, ele convoca a necessidade primeira de que, para pensar o texto literário como uma fotografia, sejam identificados os testemunhos latentes ("studium"- BARTHES, 2009a) e, a partir deles, sejam estabelecidas as bases para questionar o que, na relação com a obra literária, assegura a sobrevivência psíquica do homem, promovendo a sensação do "por vir" que advém em imagem - o "poderia ser", tão próximo da noção de "punctum" (BARTHES, 2009a).

Como forma de atender à demanda exigida por esses questionamentos, o andamento deste artigo está organizado em duas sessões, além da introdução e das considerações finais. Na primeira, as noções de língua e de linguagem (BENVENISTE, $1995,2006,2014)$ formam as bases para discussão, assim como permitem que sejam destacados os primeiros indícios da possibilidade de que a literatura possa agir como arte visual. Em seguida, a reflexão construída no primeiro item é convocada diante dos estudos de BARTHES (2009a) sobre a fotografia, refletindo na possibilidade de que a literatura se dê a ver como imagem fotográfica. Respaldo para a investigação, assim como está organizada, encontra-se nas palavras de Hartman (2008, p. 224), para quem encarar com seriedade as formas de representação que a arte pode evocar é ter consciência do poder que ela tem para "[...] mover, influenciar, ofender e ferir"; pois ela gera, segundo o autor, uma espécie de transe, "[...] preparando tanto o autor quanto o ouvinte para uma experiência terrível ou sublime, sempre prestes a acontecer, ou que já aconteceu”.

\section{A recepção do testemunho latente: implicações de linguagem e de língua}

A literatura e a fotografia, como fatos de linguagem que são, necessitam do querer-dizer de um sujeito que as realize enquanto potência em ato, ou seja, que as arranque do lugar da inexistência para as enunciar, permitindo-as emergir como espaço de significação. Ambas nascem como imagem, a partir de elaboração prévia, em linguagem interior, cuja característica é ser alusiva. Conforme, Benveniste (2014, p. 132), "[...] a linguagem interior é rápida, incoerente, pois sempre se compreende a si mesma. É sempre uma língua situada, em um contexto presente, [...] inteligível para o falante e apenas para ele $[\ldots] "$. 
Tão impossível de negar quanto a motivação humana que permite o nascer de uma obra literária ou de uma imagem fotográfica, é o fato de que a língua que constrói e que pode ser lida em ambas as substância (literário e imagético), ao primeiro olhar é código, é registro, é imagem arranjada em sistema semiótico que comporta (cada qual a seu modo) um conjunto de signos.

No entanto, não é novidade afirmar que o processo de recepção não se encerra no contato de primeira instância (visual), já que, concomitantemente, o processo metalinguístico de interpretação emerge como manifestação psíquica singular acerca do objeto contemplado. Nesse sentido, a subjetividade do leitor da imagem fotográfica ou a do receptor de um texto literário pode ser definida "[...] não pelo sentimento que cada um experimenta de ser ele mesmo (esse sentimento, na medida em que podemos considerálo, não é mais que um reflexo), mas como a unidade psíquica que transcende a totalidade das experiências vividas que reúne, e que assegura a permanência da consciência" (BENVENISTE, 1995, p. 286).

Os estudos linguísticos definem um signo como unidade psíquica dotada de significação. Para Saussure (2008), um signo é a união entre um significante e um significado. Para Benveniste (1995, 2006), abrindo as dimensões da proposta saussuriana, o signo comporta as faces semiótica e semântica. A primeira está para o reconhecer, a segunda está para a significação. "O que não é usado não é signo; e fora do uso o signo não existe” (BENVENISTE, 2006, p. 227), o caráter semiótico é responsável por fundar a existência de um signo e por assegurar com que ele seja partilhado entre os indivíduos de uma mesma comunidade.

É, portanto, o semiótico o que viabiliza a recepção, já que tem por característica garantir certa estabilidade a um conjunto de signos. Ao primeiro contato, conforme mencionado, no texto literário e na imagem fotográfica o equilíbrio é garantido pelo conjunto de signos que os suporta. Naquele, a palavra escrita (gráfica); nessa, um fragmento de realidade escrito com luz. Porém, o processo de significação não decorre unicamente do reconhecimento/recepção dos fatos denotados, uma vez que eles asseguram a leitura, em ambos os sistemas, a nível de código. A significação é proveniente da possibilidade de que os elementos dispostos nos sistemas em evidência toquem o homem e o desloquem para dentro de si, daí a possibilidade de que os fatos de linguagem sejam recebidos e interpretados a partir da experiência adquirida pelos locutores na e pelo uso da língua.

$\mathrm{O}$ eu experimenta a si mesmo antes de estabelecer a referência na instância de enunciação para a qual parte tendo como bagagem não toda a potência dos ditos e não ditos, tampouco a "língua toda", mas aquilo que herdou do sistema, sua língua-discurso, cujas unidades, as palavras, quando postas em ação na instância de enunciação, testemunham sobre ele mesmo. A sentença "falar a partir de si" faz sentido quando se considera que cada enunciação parte e retorna a quem a profere, uma vez que nos constituímos intersubjetivamente na interação com o outro, para quem orientamos e "moldamos" nosso dizer [...]. (KLAFKE, 2016b, p. 27) 
A ideia de língua-discurso ${ }^{3}$ trazida na citação acima tem inspiração na noção que pode ser lida na obra benvenistiana, e significa, neste contexto, que o homem em posição de dizer (seja uma enunciação visual ou verbal) o faz, em primeira instância, a partir da experiência de ser a si mesmo. Nesse processo, ao se propor como sujeito de um discurso, pela subjetivação da língua, o homem perpetua e transforma o mundo.

Do ponto de vista semiótico, tanto a imagem fotográfica quanto o texto literário revelam a autossemiotização da língua em uma substância que não é ela, uma vez que ambos os sistemas operam como suportes que criam a impressão psíquica visual das instâncias por meio das quais adquirimos experiências nos diferentes momentos em que fizemos uso da língua e a subjetivamos em virtude de nossa necessidade de existir (ocupar lugar na cadeia discursiva e, por consequência, no mundo).

Ao mencionar a expressão "implicação de si", neste item, já nos deslocamos para os processos de significação e de resgate que metalinguisticamente opera o expectador/leitor de imagem e de texto, o que nos conduz ao próximo tópico deste artigo.

\section{Explorando a imagem da palavra e a palavra que dá vida à imagem: uma fotografia literária}

Conforme visto até aqui, é sobre a dimensão semiótica que recai a composição de um conjunto signos e a capacidade de que o conjunto seja recebido/reconhecido pelos indivíduos de um mesmo grupo social. Contudo, como o processo de interpretar não permanece em nível semiótico, é na dimensão semântica que nos encontramos no limiar da significação, sendo ela responsável pela realização da significância engendrada pelo discurso. Considerando a ideia de uma língua-discurso, essa construção individual que se constitui a cada experiência singular de uso da língua, entendemos que "o semântico particular que preenche as palavras de minha língua-discurso deixa transparecer minha visão de mundo, minha forma de subjetivar a língua. Só eu sou capaz de saber qual é sensação de lidar com as palavras de minha língua-discurso e com o discurso que organizo com elas" (KLAFKE, 2016b, p. 31).

Com a posição acerca de uma língua-discurso fundada sobre a possibilidade de um semântico particular (que está para a significação, portanto para além do significado socialmente partilhado), podemos nos voltar para a obra de Barthes (2009a) e nela explorar a noção de studium. Para o autor, essa categoria abriga o testemunho não velado sobre dada realidade. Em outras palavras, trata-se dos elementos denotados, daquilo que

\footnotetext{
${ }^{3}$ Em dissertação, intitulada Discurso: em busca da essência do pensamento de Émile Benveniste e defendida no ano de 2014, no Curso de Pós-Graduação em Linguística Aplicada da Universidade do Vale do Rio dos Sinos, Natália de Almeida Souza buscou elucidar a noção de discurso que emerge da obra do linguista sírio. A pesquisadora, a partir de minuciosa investigação do termo em âmbito linguístico e no âmbito da teoria de Benveniste, chega ao conceito de língua-discurso. Para ela, a língua-discurso pode assim ser compreendida: "a língua de que cada indivíduo dispõe não é fielmente a langue de Saussure. O semiótico que acessamos não é língua-sistema, pois esta é social e muito dela nos foge. O que acessamos é a nossa língua-discurso, a nossa 'multiplicidade indefinida de frases possíveis', a parte da língua-sistema que já não nos escapa mais e sobre a qual temos relativo domínio. A língua-discurso é o semiótico particular de cada locutor, de cada um de nós" (SOUZA ALMEIDA, 2014, p. 58).
} 
a fotografia traz como latente e que facilmente encontra correspondência no mundo empírico.

Do ponto de vista de um sistema de signos, cada um dos elementos que compõem uma imagem fotográfica relaciona-se entre si pela diferença que os une e, em número finito, forma o todo visual do qual advém a significação. Se considerarmos a proposta barthesiana para pensarmos a arte que se constitui pela palavra, percebemos algo de semelhante no tange ao arranjo dos elementos que compõem a tessitura textual. No processo de escrita de um poema, por exemplo,

[...] a nova palavra entra em relação com os outros elementos na frase, mas também com todas as palavras precedentes, e a frase que ela contribui para constituir entra em relação com as frases já escritas. Ali onde se persegue a escrita, poucas palavras são possíveis. (JURANVILLE, 1987, p. 253)

Os elementos significantes que constroem uma imagem fotográfica são os signos que a constituem como sistema e da mesma maneira acontece com as palavras que compõem o tex to de literatura. Na imagem, os elementos (unidades) que a constituem, da mesma forma que as palavras em uma obra, colaboram para a formação de um posicionamento sobre o mundo. Tal como na escrita de que trata de Benveniste (2014, p. 157), escrever, seja com luz ou não, é também observar uma mudança de função: “[...] de instrumento para iconizar o real, ou seja, o referente, a partir do discurso, ela se torna, pouco a pouco, o meio de representar o próprio discurso [...]”.

Sendo assim, tanto na imagem quanto na literatura são as relações estabelecidas pelos elementos que as compõem as responsáveis pela diferença semiótica que os une e pela semântica que permite a identificação desses elementos com as instâncias discursivas. Isso significa que o papel da língua como interpretante é o de garantir certa estabilidade no processo de leitura de texto ou de fotografia, pois, "ao nível da mensagem 'simbólica', a mensagem linguística orienta já não a identificação, mas a interpretação, ela constitui uma espécie de grampo que impede os sentidos conotados de proliferarem [...]" (BARTHES, 2009b, p. 34).

São, portanto, as unidades formadoras de texto e de imagem que orientam a leitura para que o receptor da obra encontre o discurso que delas advém e é a partir do alcance, da interpretação e do encontro com a materialidade discursiva que a literatura e a fotografia têm as barreias desfeitas entre si. Não é mais possível dizer onde começa uma e onde a outra termina, porque no momento em que o receptor da obra encontra o discurso e o toca, preenchendo-o e a si mesmo de significação, é porque encontra a linguagem e, sobre ela, não se pode dizer, só se pode sentir: "a linguagem serve para viver", como nos ensina Benveniste (2006, p. 122).

A "sensação" proveniente da imagem que advém do todo discursivo, do ponto de vista dos fatos denotados, é de uma legitimidade (existe ou não existe/reconhecimento) capaz de criar um efeito de realidade. Para Descartes, todo ato de visão é um juízo intelectual de um sujeito pensante, e que sua base é fundamentada por um "eu penso ver, uma reflexão do Eu a partir dos signos sensíveis pintados sobre o fundo do olho". (AGAMBEN, 2015, p. 94). Logo, a fotografia não é língua, mas a contém e a simboliza em uma substância que não é ela, mas que dela necessita para existir. 
Isso quer dizer que o falante se detém sobre a língua em vez de se deter sobre as coisas enunciadas; ele leva em consideração a língua e a descobre significante; ele observa recorrências, identidades, diferenças parciais, e essas observações se fixam em representações gráficas que objetivam a língua e que suscitam, enquanto imagens, a própria materialidade da língua. (BENVENISTE, 2014, p. 155)

Não podemos esquecer, no entanto, que, no processo de recepção de texto e de imagem "[...] a relação do olhar com aquilo que se quer ver é uma relação de logro. O sujeito apresenta-se como um outro que ele não é, e aquilo que lhe é dado ver não é aquilo que ele quer ver" (BARTHES, 2009b, p. 303). O que o homem acessa por meio da imagem é proveniente do todo discursivo captado no processo de recepção, estando para além do registro de significantes. Como saída da teia significante, Barthes (2009a) nos oferece a ideia de punctum, entendida como lugar de não coincidência e não linearidade. Nessa concepção, a interpretância foge para a dimensão discursiva em que os fragmentos de memória adquiridos pelo homem, nos diferentes "aqui-agora" que experienciou ao longo da vida, tencionam a rigidez do fato denotado e explodem em "[...] incapacidade de recepção de um evento que vai além dos 'limites' da nossa percepção e torna-se, para nós, algo sem forma" (SELIGMANN-SILVA, 2000, p. 84).

Ao que não tem forma, denomina-se língua em estado de arte. Não tem forma porque não pode ser dita. A língua em estado de arte toca a linguagem. Ela é elaborada a partir da individual de cada um de nós (língua-discurso), mas, diferentemente dela, não expressa um dizer em palavras, mas sim um sentir (significação):

O significado mais profundo da imagem não se encontra necessariamente explícito. O significado é imaterial; jamais foi ou virá a ser um assunto visível passível de ser retratado fotograficamente. $\mathrm{O}$ vestígio da vida cristalizado na imagem fotográfica passa a ter sentido no momento em que se tenha conhecimento e se compreendam os elos da cadeia de fatos ausentes da imagem, além da verdade iconográfica. (KOSSOY, 2012, p. 130.)

A língua em estado de arte é a própria emanação do $e u$ (eu, aqui, diz respeito à categoria antropológica, anterior ao eu como posição discursiva) que foi desestabilizado pelo objeto artístico. Diz-se "emanação do eu" no sentido de que entrar em contato com a língua em estado de arte é ser testemunha de uma experiência que não é comportado pela mesma matéria de que é feita a palavra. Nesse processo, o homem, por uma fração de tempo, não encontra para si posição na teia discursiva (não consegue fazer-se locutor) ao mesmo tempo em que experimenta o eclodir, em si mesmo, do sentir que o transporta de uma realidade íntima e individual à uma realidade socialmente construída. "[...] o locutor é o laço que une a língua sistêmica e a sociedade, a língua individual e a cultura, é o pêndulo que vibra entre vida mental e vida em sociedade". (KLAFKE, 2016, p. 44). Sendo assim, pode-se dizer que a língua em estado de arte emerge quando há o reconhecimento para além daquilo que a imagem denota, é o traço volitivo-emocional que preenche o abismo entre o homem e a arte. "A linguagem é aquilo sobre o qual não se pode dizer, a língua é o que permite a relação entre o homem e as coisas do mundo, é o dispositivo que o transporta para o sentir" (KLAFKE, 2016, p. 128). A significação que decorre deste processo pode ser entendida como a captura, pelo contemplador, do discurso que advém do todo. 
"Entrar em contato com a língua em estado de arte pesa, porque ela é o espaço de onde só é possível retornar quando se faz o movimento de (re)encontrar, no tempo-espaço de enunciação, um lugar para si, dessubjetivando e subjetivando novamente a matéria significante". (KLAFKE, 2016, p. 128). Por isso, é possível dizer que o receptor de texto de literatura e de imagem fotográfica subjetiva, ao entrar em contato com a matéria significante que organiza ambos os sistemas, a partir do sentido provenientes de cada um deles, e produz significação a ponto de permitir com que a realidade (no sentido benvenistiano, portanto discursivo) penetre-lhe a consciência.

Isso quer dizer que a experiência humana na linguagem é o que assegura com que o discurso proveniente do texto de literatura revolva o conjunto simbólico do qual o homem faz parte e o instigue, ao convocar traços de uma realidade positiva, a representar o mundo (que emerge do todo discursivo) em imagem. "A imagem fotográfica não pode ser enclausurada pelo registro iconográfico, especialmente pela implicação humana que recorta e registra a representação do mundo que ela expressa" (KLAFKE, 2016, p. 98), pois quem elabora uma imagem conta um pouco do que vê ao mesmo tempo em que revela um pouco de si.

\section{Considerações finais}

Ao longo deste artigo optou-se, a partir da abordagem enunciativa dos estudos da linguagem, por indicar, tendo por base a relação entre homem, linguagem e língua, visões teóricas que aproximem a literatura e a fotografia, assim como estabelecer uma hipótese, tendo em vista a noção de discurso como substância que transporta a possibilidade de que o texto se dê a ver como imagem, para que o literário emerja como visualidade.

Sendo assim, o primeiro ponto que esta reflexão permite alcançar é o de que o receptor de imagem e de texto literário, após a decodificação dos fatos denotados pelos sistemas, os subjetiva a partir de um novo reconhecimento de si mesmo. Com isso se quer dizer que é a memória social fundada pelas diversas experiências do homem na e pelo uso da língua que o conduzem a conectar-se, no processo de recepção, com o conjunto simbólico que o constitui como ser no mundo. Dessa maneira, a literatura emerge como imagem para o homem porque convoca para além do mundo do significante, ela ruma para o desconhecido ao estimular a sensação de "poderia ser", pois, "na nossa relação com as coisas, tal como ela se constitui através da visão e ordena nas figuras da representação, há algo que se resvala, passa, se transmite de estádio para estádio, para aí ser sempre elidido num grau qualquer [...]" (BARTHES, 2009b, p. 303).

Se é verdadeiro que a literatura é o meio que assegura a sobrevivência psíquica do homem, promovendo a sensação do "por vir" que advém em imagem, como uma fotografia, é porque ela não coloca o homem em relação a outra coisa senão a si mesmo. A cada ato-processo de recepção do texto literário, a imagem elaborada metadiscursivamente pelo homem atualiza-se como um ponto de vista sobre o mundo e renova-se em potência quando o contemplador reconstrói a sua (e a própria) existência na cadeia significante ao preencher, com sua língua (língua-discurso) (KLAFKE, 2016), o abismo que a separa do discurso que advém da obra. 
A literatura, tal como a fotografia, não admite uma interpretação qualquer, assim como também não é isenta, isto é, ela se apresenta ao interlocutor como um espaço saturado de valores em concorrência entre si e direciona o olhar do contemplador para que ele capture o discurso que dela emana, pela relação convocada pelos elementos postos em cadeia no conjunto da obra. "A imagem atualizada em discurso dá a ver a capacidade de autossemiotização da língua em algo que não é ela [...] A língua preenche aquilo que falta na unidade da imagem, mas, para que isso aconteça, temos o papel do homem como contemplador a movimentar a maquinaria lógico-ontológica da linguagem. (KLAFKE, 2016, p. 141)

\section{Referências}

AGAMBEN, Giorgio. A potência do pensamento. Ensaios e conferências. Trad. Bras. Belo Horizonte: Autêntica, 2015.

AGAMBEN, Giorgio. O fim do poema. Trad. Bras. REVISTA CACTO, ago. 2012d.

BHABHA, Homi K. O local da cultura. Belo Horizonte: Ed. daUFMG, 1998.

BARTHES, Roland. A câmara clara: nota sobre a fotografia. Lisboa: Edições 70, 2009ª . O óbvio e o obtuso. Lisboa: Edições 70, 2009 b.

BENVENISTE, Émile. Problemas de Lingüística Geral I. Campinas: Pontes, 1995. Problemas de Linguística geral II. Campinas: Pontes, 2006.

HARTMAN, Geoffrey H. Holocausto, testemunho, arte e trauma. Em: NESTROVSKY, A.; SELIGMANN-SILVA, M. (Orgs.). Catástrofe e representação. São Paulo: Escuta, 2000. p. 207-235.

JURANVILLE, A. Lacan e a Filosofia. Trad. Bras. Rio de Janeiro: Zahar Editor, 1984.

KLAFKE, Sandra. Da (re)criação enunciativa da experiência humana : a fotografia como testemunho. Tese. Doutorado em Linguística Aplicada. Universidade do Vale do Rio dos Sinos, Programa de Pós-Graduação em Linguística Aplicada, 2016a.

Experimentar(-se) (n)a consciência sobre si mesmo: a ideia da aventura humana na e pela linguagem. REVEL, edição especial n. 11, 2016b. Disponível em http://www.revel.inf.br/files/e1c1ca3af6c0e280ae064c50df925d5d.pdf. Acesso: 20 julho de 2016.

KOSSOY, Boris. Fotografia e história. São Paulo: Ática, 2012.

SAUSSURE, Ferdinand. Curso de Linguística Geral. São Paulo: Cultrix, 2008. 
SELIGMANN-SILVA, Márcio. A história como trauma. Em: NESTROVSKY, Arthur; SELIGMANN-SILVA, Márcio (Orgs.). Catástrofe e representação. São Paulo: Escuta, 2000. p. 73-98.

SOUZA ALMEIDA, Natália Cristina de. Discurso: em busca da essência do pensamento de Émile Benveniste. Dissertação. Mestrado em Linguística Aplicada. Universidade do Vale do Rio dos Sinos, Programa de Pós-Graduação em Linguística Aplicada, São Leopoldo, RS, 2014.

Artigo recebido em: maio de 2017.

Aprovado e revisado em: setembro de 2017.

Publicado em: novembro de 2017.

\section{Para citar este texto:}

KLAFKE, Sandra. Ler a imagem fotográfica, contemplar o texto literário: im(com)plicações de linguagem. Entremeios [Revista de Estudos do Discurso, on-line, www.entremeios.inf.br], Seção Estudos, Programa de Pós-Graduação em Ciências da Linguagem (PPGCL), Universidade do Vale do Sapucaí (UNIVÁS), Pouso Alegre (MG), vol. 15, p. 03-12, jul. - dez. 2017.

DOI: http://dx.doi.org/10.20337/ISSN2179-3514revistaENTREMEIOSvol15pagina03a12 